\title{
Implicature and Deixis of Novel Laskar Pelangi and Novel Mimpi-Mimpi Lintang by Andrea Hirata
}

\author{
Sitti Aida Azis ${ }^{1}$, Aziz Thaba ${ }^{2, *}$, Rukayah ${ }^{3}$, Abdul Kadir ${ }^{4}$ \\ ${ }^{1}$ Postgraduate School, Muhammadiyah University of Makassar, South Sulawesi, Indonesia \\ ${ }^{2}$ Researcher at Matutu: Non-Governmental Education Research and Development, South Sulawesi, Indonesia \\ ${ }^{3}$ Faculty of Science Education, State University of Makassar, South Sulawesi, Indonesia \\ ${ }^{4}$ Faculty of Teacher Training and Education, Cokroaminoto Pinrang College of Teacher Training and Education, South Sulawesi, Indonesia
}

Email address:

azizthaba@yahoo.co.id (A. Thaba)

${ }^{*}$ Corresponding author

\section{To cite this article:}

Sitti Aida Azis, Aziz Thaba, Rukayah, Abdul Kadir. Implicature and Deixis of Novel Laskar Pelangi and Novel Mimpi-Mimpi Lintang by Andrea Hirata. International Journal of Literature and Arts. Vol. 8, No. 4, 2020, pp. 245-254. doi: 10.11648/j.ijla.20200804.20

Received: June 20, 2020; Accepted: July 8, 2020; Published: July 17, 2020

\begin{abstract}
The purpose of this study are; (1) Describe the implicatures contained in the Laskar Pelangi novel and the dreams of Lintang Maryamah Karpov by Andrea Hirata, (2) Describe deixis contained in the Laskar Pelangi novel and the dreams of Lintang Maryamah Karpov by Andrea Hirata. This research includes qualitative descriptive research. The focus of this research is identifying; (1) variety and form of implicature (2) variety of deixis. Data collection uses marking reading techniques and note taking techniques. Data analysis using the mindset includes; (1) data reduction, (2) presentation, and (3) data conclusions and verification. The results of this study, namely the variety of implicatures contained in the novel Laskar Pelangi by Andrea Hirata are divided into three, namely conventional implicatures, presupposition implicatures, and nonconventional implicatures. The various implicatures are then realized in four forms, namely sentence statements, command sentences, question sentences, and exclamation sentences. Similarly, the novel Laskar Pelangi novel by Andrea Hirata Maryamah Karpov was found to range and form the same implicatures. Deixis in the novel Laskar Pelangi by Andrea Hirata can be divided into five, namely individual deixis, place deixis, time deixis, discourse deixis, and social deixis. Individual deixis is divided into two, namely the first person deixis and the third person deixis. Deixis place is divided into three, namely proximal deixis, semiproximal deixis, and distal deixis. Deixis time divided into three namely deixis plainly past, deixis present, and future deixis. Discourse deixis is divided into two, namely anaphora deixis and katafora deixis. Social deixis is divided into two, namely deixis euphemism and deixis of honorifics. The five deixis are also found in Maryamah Karpov's novel. But, in Maryamah Karpov's novel, the variety of katafora dixis is not found.
\end{abstract}

Keywords: Implicature, Deixis, Novel

\section{Introduction}

The substance of literary form is language. Language is meaningful sound symbols that are conventions. Therefore, to be able to understand literature one must first be able to understand language. In literature, there are messages that have been convested and also those that are not. This unconventional message that requires work to understand it.

As is the case with the Laskar Pelangi novel and MimpiMimpi Lintang Maryamah Karpov by Andrea Hirata. Both novels require extra work to understand and explore the contents contained in them. In the process of creation, language by Andrea Hirata is a tool to establish communication with readers. But not with the language principles. The principle referred to here is the power or language ability of Andrea Hirata by putting meaning that is understood, internalized, and becomes the principle of his life. There are messages or meanings that are displayed in a straightforward manner, but not a few are displayed abstractly. Thus the attractiveness of displayed by Andrea Hirata in the novel, especially in the novel of Laskar Pelangi 
and Mimpi-Mimpi Lintang Maryamah Karpov with his language style.

Reading literature is essentially communicating indirectly with the authors of the writings we read. For this reason, between readers of literature and authors must have an understanding of language and meaning itself. Because, the success of communication can be achieved if there is an understanding between speakers and opponents of speech or in other words the opponent can understand the meaning of speech [1]. For this reason, studying the meanings conveyed by speakers (writers) and interpreted by listeners directs the reader to the action of studying language with a pragmatic theory. Crystal [2] states that pragmatics examines the factors that drive the choice of language in social interaction and influence the selection of the hearer. It means, even though theoretically it must refer to established language rules, but often in practice language is not enough to just follow the rules, constructing a sentence must always relate it to the context in which the speech is built and the context outside the speech itself.

As well as literature, the reader should be able to capture the messages conveyed by the author through the fabric of the story. The explicit message may be easily understood by the reader. But the literature is a work of imagination that is full of connotation content in it, certainly contains many messages or meanings that are implicit in nature. For this reason, pragmatics is present as a scalpel for various symptoms and linguistic phenomena in literature as described above. Pragmatics is one branch of linguistics. Pragmatics is the study of the relationship between linguistic forms and the use of those forms. Crystal [2] states that pragmatics examines the factors that drive the choice of language in social interaction and influence the selection of the hearer. Pragmatics studies are divided into four, namely implicature, deixis, presuppositions, and speech acts.

Implicature is the relationship between the utterances spoken between two people who are talking. This connection does not appear literally, but is only understood implicitly. The concept of implicature was first introduced by Grice, Cole and Morgan [3] to solve the problem of language meaning that cannot be solved by ordinary semantic theory. Implications are used to calculate what is suggested or what is meant by speakers as something different from what is literally stated. By Grice, implicature is divided into three parts, conventional implicatures, presuppositions, and unconventional implicatures. The manifestation of own implicature according to Huang [4] is the expression of sentences from speakers. Implicit sentences are divided into four, namely statement sentences, questions, commands, and exclamations.

Deixis is also called lexical and grammatical contextual information which refers to certain things, whether objects, places or times. Deiksis discusses expressions or contexts in a sentence. There are five types of deixis, namely people deixis, place deixis, time deixis, discourse deixis and social deixis [5].

\section{Literature Review}

\subsection{Discourse}

\subsubsection{Definition of Discourse}

The term discourse comes from Sanskrit which means "utterance or speech" [6] This is in agreement with Douglas [7] that the term "discourse" comes from the Sanskrit wac/ wak / vak, which means 'say' or 'say'. The word then undergoes change into discourse. The form of ana that appears behind is a suffix (suffix), which means 'to settle' (nominalization). So, the word discourse can be interpreted as 'sayings' or 'utterances'.

\subsubsection{Elements of Discourse}

i. Internal Elements of Discourse

a. Words and sentences

According to Foker [7] a sentence is a speech that has a full meaning and the overall limit is determined by intonation (perfect). The meaningfulness of a sentence is determined by the meaning of the other sentence which is the sequence. So, according to the opinions stated above, it is clear that words and sentences are elements that must be in the discourse.

b. Text and context

Text is the essence of language and text is realized in the form of discourse. Text is a term that means closer to written language [7]. So, the text can be equated to a script, which is a kind of writing material that contains certain material, such as scripts for lecture material, speeches and others.

ii. External Elements of Discourse

a. Implicature

Implicature is a meaning implied in a speech both oral and written. Within the scope of discourse analysis, implicature means something that is involved or becomes the subject of discussion. Implicature functions as a bridge between "spoken" and "implied".

\section{b. Presupposition}

The term presupposition comes from English presupposition, which means 'mind or presumption' [8]. He added, presuppositions or presumption is basic conclusions about contexts and language situations that make language forms have meaning for listeners and on the contrary help the speaker determine the forms of language that can be used to express the intended meaning or message.

c. Reference

Reference is the relationship between a word and an object (person, plant, or something else) that it refers to. Reference is the behavior of the speaker or writer [7].

d. Inference

Etymologically, inference comes from the inference word which means conclusion. The term inference in the field of discourse means a process that must be carried out by the reader to understand the meaning that is literally not expressed by the author or writer. According to Mulyana [7] the reader must be able to take understanding or interpretation of a particular meaning contained in the discourse.

e. Context 
The context of discourse is very necessary in analyzing a discourse. Context is the situation or setting of communication. Context can be considered as a cause and reason for a speech or dialogue [7].

\subsubsection{The Principle of Understanding Discourse}

Understanding a discourse requires certain abilities and ways. Capability is related to the general knowledge of a discourse analyst, while the intended method is the principles of understanding discourse. The principle of understanding the discourse is the principle of analogy and the principle of local interpretation [7]. How a discourse analyst can understand the discourse well, will be explained as follows.

\section{i. Principle of Analogy}

A discourse basically contains a number of knowledge and information that is not easily understood by readers or listeners. Therefore, a certain way is needed to understand the things that are actually informed and intended by the discourse. One of the most important and fundamental principles of understanding discourse is the principle of analogy. Thing that need to be considered in this principle is the need for general knowledge, deep insight, or extensive world experience (knowledge of world) to analyze discourse.

ii. The Principle of Local Interpretation

The principle of local interpretation or local interpretation principle used as a basis for interpreting the discourse by looking for the context surrounding the discourse. The context in question is the area, or the local (setting) where the discourse is located. The context depends on the type of discourse being analyzed. If the discourse is written, then the context or local in question is the context around the media used as the birth of the discourse.

\subsection{Pragmatics}

\subsubsection{Definition of Pragmatics}

Pragmatics is the study of the relationship between linguistic forms and the use of those forms. Pragmatics examines the meaning of speech, pragmatics learns the structure of language externally, namely how language units are used in communication. Crystal [2] states that pragmatics examines factors that encourage language choice in social interactions and the influence of that choice on speech partners. That is, even though theoretically it must refer to established language rules, but often in practice language is not enough to just follow the rules, constructing the sentence must always relate it to the context in which the speech act is built.

\subsubsection{Scope of Pragmatics}

\section{i. Deixis}

Deixis is the relationship between words used in speech acts with referents that word that is not fixed or can change and move [9]. Designation or deixis is the location and identification of people, objects, events, processes or activities that are being discussed or that are being referred to in relation to the dimensions of space and time, when spoken by the speaker or invited to speak [10].

ii. Presumption

Presumption is something assumed by speakers as an event before producing a speech. Presumption in speech acts is "additional" meaning or information contained in speech used implicitly [9].

iii. Implicature

The concept of implicature was first introduced by Grice, Cole and Morgan [3] to solve the problem of language meaning that cannot be solved by ordinary semantic theory. Implicature is used to calculate what is suggested or what is meant by speakers as something different from what is stated literally [11]. What is meant by conversation implicature is the relationship between the utterances spoken between two people who are talking.

iv. Speech Act

The first expert to introduce speech act theory and theory was Austin in 1962. Austin was a professor at Harvard University. The theory comes from lectures which were then recorded by Searle, Kiefer and Bierwisch [12] with the title "How to do things with words?" However, this theory only developed and became known in the world of linguistics after [13] published a book entitled" Peect Act, and Essay in the Philosophy of Language" [14].

\subsection{Implicature}

\subsubsection{Definition of Implicature}

Implicature is one part of pragmatics. Implicature of conversation was originally put forward by a philosopher named H. Paul Grice in a "William James Lecture "at Harvard University in (1967). His writing entitled "Logic and Conversation" was proposed to overcome the problems of language mafia which cannot be explained by theory linguistic language [3]. The concept of implicature which was first introduced by Grice to solve the problem of language meaning that cannot be solved by ordinary semantic theory. If only relying on theory or semantic understanding only, the meaning of speech or speech cannot be understood and understood correctly.

Furthermore, Lubis [16] states that implicature is the meaning or aspect of the meaning of pragmatics. Thus, only a part of the literal meaning (harafiah) which supports the true meaning of a sentence, the rest comes from the facts that exist (this world) both the situation and conditions. Then, Brown and Yule [17] state that implicature is used to explain what might be interpreted, suggested, or intended by speakers as something different from what is actually said by speakers. In line with this, Samsuri [18] suggests that conversational implicatures are used to consider what can be suggested or intended by speakers as something different from what appears literally.

\subsubsection{Variety of Implicatures}

According to Grice, Cole and Morgan [2], there are three types of conversational implicatures namely: conventional implicatures, presuppositions, and unconventional implicatures. 
a. Conventional implicature, that is, implicature obtained directly from the meaning of the word, and not from the principle of conversation. Conventional implicature refers more to conventional word meanings, the meaning of conversation is determined by the "conventional meaning" of words used. For example: "Atun is deaf, therefore she cannot speak". The implicature of the speech is that Atun cannot speak is a consequence because she is deaf. If Atun is not deaf, of course the speech does not imply that Atun cannot speak because she is deaf.

b. Presupposition implicature is the speaker's suggestion that the partner can know the person or thing that is said. A speech can presume another speech. Pre-supposition refers to a shared knowledge between speakers and speech partners. For example: "Budiono drinks Aqua". From this example, it can be concluded that the presupposition of the speech is "There is an Aqua brand drink" or "Aqua is a drink that can be drunk like tea, coffee, or other drinks".

c. Nonconventional Implicature, is an implicature that bases its meaning on the context surrounding a conversation. Unconventional implicature is the pragmatic implicit implication in a conversation. For example: "Wow, Mr. Win is now a person". The implicature of the speech conversation is that Pak Win was not successful, because "people" in the speech were meant to be "successful people".

\subsubsection{Form of Implicature}

According to Huang [4] in implicature, the form of implicature commonly used by speakers is a speech form used by speakers to convey messages to verbal speech partners in a conversation, in which the form of speech that is based on meaning outside the linguistic form. Its concrete form in French grammar is laphrase declarative (statement sentence), interrogative phrase (question sentence), la phrase imperative and la phrase exclamative (exclamation sentence).

\subsection{Deixis}

\subsubsection{Definition of Deixis}

According to Purwo [19] deixis is a word said to be deixis if it changes depending on who is the speaker and depends on the time and place the word is said, for example: my word, here, now. Lyons and John [5] gives the notion that deixis comes from a Greek word which means "to point" or "show" this has become a technical term in grammar theory, to deal with the characteristics of "determination" of language related to character and place of speech. In Pendidikan and Kebudayaan [20], deixis is defined as a thing or function that points to something outside the language; pronouns, indifference, and so on.

\subsubsection{Various Deixis}

\section{i. Individual Deixis (Person Deixis)}

Individual deixis refers to the role of the participant in a conversation event such as the speaker, which is discussed, and the term person comes from the Latin persona as a translation of the Greek word "prosop on" which means the mask (mask used by a showman) also means the role or character performed by drama players, [19]. Still according to Purwo, person deixis is determined according to the role of participants in language events.

ii. Place Deiksis (Place Deixis)

Referring to the location, in English there are adverb places here and there. Cahyono [21] gives the notion of place deixis is giving form to locations according to participants in language events. All languages including Indonesian distinguish between "close to the speaker" (including those close to the listener (it).

iii. Deixis Time (Time Deixis)

Cahyono [21] describes time deixis as giving form in the time span as intended by speakers in language events. Deixis time refers to the time of occurrence of events, both past, present, and future [6]. Provides an example of time deixis in the following discourse.

\section{iv. Deixis Discourse (Discourse Deixis)}

Discourse deixis is deixis which refers to the references that exist in discourse and is intratekstual [6]. In Cahyono [21] deixis discourse is a reference to certain parts of the discourse that have been given or are being developed. Discourse deixis includes anaphora and katafora. Anaphora is the reappointment of something previously mentioned in a discourse with repetition or substitution. Katafora is the designation of the things mentioned later.

v. Social Deixis (Social Deixis)

Social deixis refers to social relations or social differences. Deixis is defined as an expression that is bound to the context For example in the phrase "I love him", information from the pronoun "I" and "he" can only be traced from the context of the utterance. The expressions that are known only from the context of speech are what is called deixis.

\subsection{Novel}

\subsubsection{Definition Novels}

Etymologically, the novel comes from the Latin word novella which means news or notification. Novella is revealed to be an innovative word derived from an English term that means new. It can be said to be new because the novel is present as a literary genre after the poems and dramas that first existed. The novel is able to present the development of one character, complicated social situations, relationships that involve many or few characters and various complicated events that became several years ago in detail [24].

\subsubsection{Characteristics of a Novel}

A novel is a work of fiction or fiction in the form of prose. Novels as literary works have certain characteristics that can be used as guidelines. As stated by Tarigan [25] that novel features, as follows: 1) the number of words more than 35,000 pieces, 2) the average amount of time used to read the shortest novels takes at least 2 hours or 120 minutes, 3) the number of pages of the novel is at least 100 pages, 4) the 
novel depends on the perpetrator and perhaps more than one actor, 5) the novel presents more than one impression, effect and emotion, 6) broad novel scale, 7) selection on a broader novel, 8) surprises in novels are not fast enough, and 9) elements of density and intensity in novels are not prioritized.

\subsubsection{Types of Novels}

Based on its contents Lubis [16] says that the novel is the same as romance. Based on the division of Mohtar Lubis in Tarigan, the novel is divided into: 1) Avontur novel, which is centering its story on a play or hero through chronological story lines from A to Z; 2) Psychological novels are novels aimed at the examination of all the thoughts of the perpetrators; 3) Detective novels, focusing their stories on the search for evidence, whether in the form of an offender or signs; 4) Novel Political Social Affairs, this novel gives a picture of two clashing groups at a time; 5) Collective novels, this novel is the most difficult novel and has many ins and outs. Individuals as actors are not important, but prefer community stories as a totality [25].

\section{Research Result}

\subsection{Implicature in Novel Laskar Pelangi by Andrea Hirata}

\subsubsection{Various Implicatures in the Laskar Pelangi Novel by Andrea Hirata}

i. Conventional Implications

Conventional implicature is an implicature that is derived directly from the meaning of the word, and not from the principle of conversation. Conventional implicature refers more to conventional word meanings, the meaning of conversation is determined by the "conventional meaning" of words used. The quotations that explain the variety of conventional implicatures in the Laskar Pelangi novel are as follows;

"Sembilan orang... baru sembilan orang Pamanda Guru, masih kurang satu..."

(Source: Novel Laskar Pelangi, p. 2)

Based on these speeches, the conventional implicature that occurs is the number of students at that time did not meet the required needs of ten people. Because, there is still one prospective student who hasn't arrived yet.

ii. Presupposition Implications

Presupposition implications is the variety of implicatures in the form of speakers' opinions that the partner can know the person or thing that is being said. A speech can presume another speech. Presumption implicature refers more to a shared knowledge between speakers and speech partners. The excerpts that explain the variety of presuppositional implicatures in the Laskar Pelangi novel are as follows;

"Bapak Guru..."

"Terimalah Harun, Pak, karena SD hanya ada di Pulau Bangka, dan kami tak punya biaya untuk menyekolahkannya ke sana. Lagi pula lebih baik kutitipkan dia di sekolah ini daripada di rumah ia hanya mengejar-ngejar anak-anak ayamku..."

(Source: Novel Laskar Pelangi, p. 7)
The presuppositional implication of the speech arises from the awareness of Harun's parents that their child is the last students who is expected by teachers, principals, parents of students, and the students themselves so that the learning class could be opened. Seeing this situation, Ibu Harun used it in the belief that her child would be accepted into the school even though it was not normal, and the school was indeed not for persons with disabilities. The presuppositions of Ibu Harun are answered by the following utterance quotes.

iii. Nonconventional Implications

Nonconventional Implication, is an implicature that bases its meaning on the context surrounding a conversation. Unconventional implication is the pragmatic implicit implication in a conversation. The quotations that explain the variety of unconventional implicatures in the Laskar Pelangi novel by Andrea Hirata are as follows;

"Shalatlah tepat waktu, biar dapat pahala lebih banyak," demikian Bu Mus selalu menasehati kami

(Source: Novel Laskar Pelangi, p. 31)

The utterance of the data above was delivered by Ms. Mus to her students. It is said that Ms. Mus gave advice to her students by referring to the verse of Al-Quran surah Annisa which is the command to pray on time to collect more rewards. Nonconventional implication arising from the speech quotation is not what is expressed by the choice of words chosen by Bu Mus that if someone is praying on time, he will collect a lot of reward. However, praying on time at the speech has implications for efforts to achieve the peace of life of the world and the hereafter.

\subsubsection{The form of Implicature in the Laskar Pelangi Novel by Andrea Hirata}

i. Statement Sentence (Declarative Laphrase)

According to Grevisse and Goosse [26] la declarative phrase (statement sentence) is a sentence which states something. La declarative phrase in pronunciation begins with a rising intonation then ends with an intonation decreasing and the writing ends with a period punctuation (.). Implicit in the form of statement sentences in the Laskar Pelangi novel by Andrea Hirata as follows;

"Jumlah gurunya banyak"

(Source: Novel Laskar Pelangi, p. 58)

"Setiap pelajaran ada gurunya masing-masing, walaupun kau baru kelas satu."

(Source: Laskar Pelangi novel, p. 59)

Both of these speech utterances clearly use statement sentences, because the figure of Bang Amran Isnaini bin Muntazis Ilham gave a statement to the figure $I$ to convince him that in the PN school Timah had many teachers. The statement was further strengthened by an additional statement that the condition of the number of teachers in the Timah PN school was because each subject had their own teacher, even starting from the first grade.

ii. Question Sentence (La Interrogative Phrase)

According to Grevisse and Goosse [26] interrogative phrases (question sentences) are sentences that aim to obtain information or answers. In the pronunciation of interrogation 
sentences it is marked by a high intonation and the writing ends with a question mark (?). Implicature in the form of question sentences in the Laskar Pelangi novel by Andrea Hirata as follows;

"Aku hanya sendirian. Jika ada orang lain aku berani lebih frontal. Tahukah hewan ini pentingnya pendidikan? Aku tak berani lebih dekat. Ia mengangah dan bersuara rendah, suara dari perut yang menggetarkan seperti sendawa seekor singa atau seperti suara orang menggeser sebuah lemari yang sangat besar. Aku diam menunggu. Taka da jalur alternatif dan kekuatan jelas tak berimbang. Aku mulai frustasi. Suasana sunyi senyap. Yang ada hanya aku, seekor buaya ganan yang egois, dan intaian maut"

(Source: Laskar Pelangi novel, pp. 88-89)

Part of the quote shows an implicature namely "Do you know this animal is important for education?" The implication is; (1) animals (crocodiles) are uneducated creatures, (2) it becomes natural for crocodiles to block Lintang's journey to school because crocodiles are creatures that have no sense and cannot understand the noble intentions of Lintang for education at Muhammadiyah schools. The form of implicature used in the quote is in the form of a question sentence.

iii. Command Sentence (La Imperative Phrase)

According to Grevisse and Goosse [26], the phrase imperative is a sentence that contains a request or prohibition. La imperative phrases are usually marked by decreasing intonation in the pronunciation and ending with an exclamation point (!) In the writing. Implastic in the form of a command sentence in the Laskar Pelangi novel by Andrea Hirata as follows;

"Kemarilah Ayahanda... berapa empat kali empat?"

(Source: Novel Laskar Pelangi, p. 95)

The quote "Come here Father... how many four times four?" Contains the implicature that the distance between Lintang and his father is quite far, whereas to ask the question four times four, latitude must be within close proximity to his father so that his father can see the four times four. The form of the implicature used by Latitude in the quotation is the command sentence because the leech ordered his father to draw near to him. Even the question sentence is how much the result of four times four multiplication is actually a command. This was marked by the impact of the speech which obliged the father to answer the question even though he had to run to the village office. From this, it is known that there is a form of the question sentence that rules.

iv. Exclamation Sentence (La Exclamative Phrase)

According to Grevisse and Goosse [26] la phrase exclamative (exclamation sentence) is a statement sentence, but expressed with special pressure. La exclamative phrase ends with an exclamation point (!) Or period (.) In the writing. Implicature in the form of exciting sentences in the Laskar Pelangi novel by Andrea Hirata as follows;

"Kita tidak akan pernah menjadi bagian dari segerombolan penipu! Sekolah kita adalah sekolah Islam bermartabat, kita tidak akan menjual kehormatan kita demi sebuah jam tangan plastik murahan!"

(Source: Novel Laskar Pelangi, p. 152)

Implicit in the first appeal is Mahar, saying that there are groups of fraudsters who are none other than political people who always give promises of lying to the public. Implicit in the second appeal, Mahar and the other students attending Muhammadiyah Elementary School are dignified people because this is reflected in the place where they attend the SD Muhammadiyah (Islamic school) which is dignified. All forms of implicatures used by Mahar figures in these quotes are in the form of exciting sentences.

\subsection{Implicature in Maryamah Karpov's Novel by Andrea Hirata}

\subsubsection{Various Implicatures in the Laskar Pelangi Novel by Andrea Hirata \\ i. Conventional Implications \\ "Percayalah nasihatku, warna coklat muda itu akan memuatmu tampak sedikit lebih pintar"}

(Source: Maryamah Karpov's novel, p. 18)

The implication of the quote is that figure $I$ is a fool (not as smart as most people), because the word is a little smarter indicating that by wearing the new uniform, that ignorance will change just a little to be smarter. Another implication that might arise from the quote is that brown is the color that matches with character $I$. Thus, the type of implicature used by the author (Andrea Hirata) in the speech quote is conventional implicature.

ii. Presupposition Implications

Aku melonjak, tak kupercaya apa yang baru saja kudengar! "Begitukah Antonia?"

(Source: Maryamah Karpov's novel, p. 29)

Implicable from the above quote is Lintang's distrust of the story conveyed by Antonia. However, behind this distrust, Lintang had an admiration for Antonia because all this time the mathematical logic given by students in the lecture hall was always rejected by LaPlagia. By saying "Begitukan Antonia? Actually what Lintang meant was the truth of the story which was essentially understood by Antonia. From the explanation of the event, it is clear that there is a presupposing implicature between Latitude and Antonia.

iii. Nonconventional Implications

"Jangan sembarang bicara, ya, ini sumbu kompor dari Jakarta, tahu!"

(Source: Maryamah Karpov's novel, p. 47)

Implication arising from the quote is Lintang said that the stove axis has a high value which is not feasible to get reproach from Ikal when it brings it back to Indonesia. This type of implicature is nonconventional because, what is implicated by Latitude is outside of the principle of conversation or outside of the meaning of the word spoken.

\subsubsection{The Form of Implicature in the Maryamah Karpov's Novel by Andrea Hirata}

i. Statement Sentence (Declarative Laphrase)

"Aku bisa mati bosan di sini!" 
(Source: Maryamah Karpov's novel, p. 39)

The excerpt of data above is a statement from Townsend's figure that he really wanted to leave Paris. The implication used in the speech is nonconventional imprint, because the intention to be conveyed by the speaker does not refer to the meaning of the words in his speech but other meanings outside of his speech that he is eager to return to his village and leave Paris. The implicature form used is the statement sentence.

ii. Question Sentence (La Interrogative Phrase)

"Ibu, dapatkah digambarkan padaku bagaimana wajah Prof. Turnbull waktu menceritakan kepada orang-orang itu bahwa aku mahasiswa bimbingan terakhirnya?"

(Source: Maryamah Karpov's novel, p. 21)

The excerpt of data above is a question from my character to Mrs. Raina about the developing story that she heard that Prof. Turnbull often mentioned it to his colleagues. The implication used in the quotation above is conventional implicature because the purpose of the conversation in the quote is as it is written from the word or sentence used. The implicature form used is the question sentence.

iii. Command Sentence (La Imperative Phrase)

"Sudah kubilang dulu!"

"Masuk saja madrasah, mengajar mengaji, cepat-cepat cari istri, dapat pahala, dapat ransum beras!"

(Source: Maryamah Karpov's novel, p. 128)

The excerpt of data above is a curt greeting from the mother to the figure $I$ because she has been unemployed for a year and does not have a job. The sharpness of mother's character regarding her condition that didn't work is an implication of the speech. The type of implicature in the speech is nonconventional, which is manifested by the command sentence.

iv. Exclamation Sentence (La Exclamative Phrase)

"Kali ini.... para penghujat itu akan kena batunya!"

(Source: Novel Maryama Karpov, p. 255)

The excerpt of data above is Mahar's greeting to encourage Ikal which have been blasphemed by Eksyen. Implications arising from these utterances are people who blaspheme Ikal will be hit with a retaliation for the blasphemy at a time. The type of implicature used in the speech is conventional which is realized in the form of exclamation sentences.

\subsubsection{Deixis in Novel Laskar Pelangi by Andrea Hirata}

i. Individual Deixis

Individual deixis refers to the role of the participant in a conversation event such as the speaker, which is discussed.

"Kasihan ayahku..." Maka aku tak sampai hati memandang wajahnya.

"Barangkali sebaiknya aku pulang saja, melupakan keinginan sekolah, dan mengikuti jejak beberapa abang dan sepupu-sepupuku, menjadi kuli..."

(Source: Novel Laskar Pelangi, p. 3)

The quotation of data above tells about the hesitation figure of $I$ to take part in an activity at school or become a coolie because he feels sorry for his father. Particle $-k u$ in ayahku words and sepupuku is a single first person pronoun which is person deixis which refers to or refers to the author.

Deixis Place

Place deixis is a word that refers to or refers to an area or place that is indicated by speaker speech in three domains, namely deixis in close proximity (proximal), semi-remote (semiproximal), and distal. Excerpt that shows the use of deixis place in the Laskar Pelangi novel by Andrea Hirata as follows;

"Bapak Guru....,"

"Terimalah Harun, Pak, karena SLB hanya ada di Pulau Bangka, dan kami tak punya biaya untuk menyekolahkannya ke sana. Lagi pula lebih baik kutitipkan dia di sekolah ini daripada di rumah ia hanya mengejar-ngejar anak-anak ayamku..."

(Source: Novel Laskar Pelangi, p. 7)

The quote from above tells the story of Harun's mother who hopes that her son who has mental retardation can be accepted at Muhammadiyah schools. In the above discourse, words ke sana referring or pointing to a distant place or region. The designation is a form of deixis a place for distal distance.

ii. Time Deixis

Deixis of time is intended as the designation of time in a speech. Deixis time divided into three namely deixis past or the past, deixis present, deixis future will come. The three types of deixis are presented as follows;

\section{"Saya harap argumentasi mereka bisa setepat jawabannya tadi"}

(Source: Laskar Pelangi novel, p. 379)

Excerpt from data above explains the challenges of the character Drs. Zulfikar (teacher at the PN School) who challenged the $\mathrm{F}$ team (Muhammadiyah School) for their answers about Newton's rings. In the citation, the word tadi is a reference or refer to conditions or the time of the events that had passed. That is, the word is a deixis of time for the past.

\section{iii. Discourse Deixis}

Discourse deixis is deixis that uses a reference in an intertextual speech. Diexis discourse is divided into two, namely eksis anafora and eksis katafora. Anaphora is the reappointment of something previously mentioned in a discourse with repetition or substitution. Katafora is the designation of the things mentioned later. Discourse deixis in the Laskar Pelangi novel is proven by the following data;

"Kasihan ayahku..." Maka aku tak sampai hati memandang wajahnya. "Barangkali sebaiknya aku pulang saja, melupakan keinginan sekolah, dan mengikuti jejak beberapa abang dan sepupu-sepupuku, menjadi kuli..."

(Source: Novel Laskar Pelangi, p. 7)

Data quote above using particles - nya in word wajahnya to replace of a father figure has been mentioned before. Therefore, deixis of this discourse is anaphora.

iv. Social Deixis

Social deixis refers to or refers to social relations or social differences. Deixis is defined as an expression that is bound 
to the context. Deixis itself is divided into two, namely deixis euphemism and deixis honorifix. Deixis euphemism is a variety of deixis that attempts to refine the parts that are deemed inappropriate or inappropriate to be heard in order to increase the intensity of politeness between speakers and speech partners. Whereas deixis honorifix is a variety of deixis in the form of additional greetings to refine speech. The form of social deixis in the Laskar Pelangi novel can be displayed in the form of the following data citation;

"Sembilan orang...baru sembilan orang Pamanda Guru, masih kurang satu....,"

(Source: Laskar Pelangi novel, p. 381)

The quotation of the data was submitted by Ms. Mus. The above quote tells about Ms. Mus's anxiety about the number of students who came on the first day of entering elementary school. Approaching the deadline, one student never came to complete the other nine. From the incident, Mrs. Mus data to Pak Harfan who was none other than the head of the school using the Pamanda Guru greeting. The word Pamanda Guru itself is an additional greeting used by $\mathrm{Bu}$ Mus as a form of respect for Pa Harfan who is none other than his leader. So it appears that social deixis occurs through the use of the greeting which explains that between $\mathrm{Bu}$ Mus and Pak Harfan are work colleagues whose strata are different. Because $\mathrm{Bu}$ Mus is a subordinate, he should in fact give an award to his leader, Pak Harfan (Head of Muhammadiyah School). Such social deixis is called social deixis honorifix.

\subsubsection{Deixis in Maryamah Karpov's Novel by Andrea Hirata}

i. Individual Deixis

"Percayalah nasihatku, warna cokelat muda itu akan membuatmu tampak sedikit lebih pintar"

(Source: Maryamah Karpov's novel, p. 18)

The data excerpt above was delivered by Famke Somers to the figure $I$ (Ikal). This quote explains that the Famke Somers figure gave his views on the color of the costume (tie and suit) that the figure I was wearing was suitable. Use of particles $k u$ on said nasihatku refer or point to the self speaker itself is Famke Somers. While the particles - $m u$ in the word membuatmu reference or refer to the figure $I$ (Ikal). Particles $-k u$ and $-m u$ in the above quotation is equally form deixis individual (person), which refers to the first person. The difference, for particle $-k u$ refers to the first person singular, which is directly on the patron. While particle $-m u$ also refers to the first person indirectly. This form is referred to by researchers with a single second person deixis.

ii. Deiksis Place

"Aku bisa mati bosan di sini!"

(Source: Maryamah Karpov's novel, p. 39)

The excerpt of data above tells of a statement from Townsend's figure that he really wanted to leave Paris. Townsend had felt bored having lived a long time in Paris so he likened his condition to wanting to die because of a sense of boredom. The phrase di sini refers to or point to a place where Townsend figures were at that moment which is none other in the city of Paris. Thus the phrase di sini refers to a place that is close to the speaker itself, namely Townsend itself, namely Paris, so that this type is intended as a form of dexis of the proximal place, namely deiksis by designating places at close range.

iii. Time Deixis

"Terima kasih, Ikal"

"Jangan cemas, besok ada kapal berangkat"

(Source: Maryamah Karpov's novel, p. 46)

This quote explains that a thank you from Kim Lian to Ikal because he was willing to give in and let Kim Lian buy a ticket with only one left. Implicature arising from the conversation is a desire to eliminate the anxiety will nullification to return due to run out of tickets, because there are other ships that are leaving tomorrow. The word besok in these quotations refer or refers to the time that will come. The use of the word that refers to the time indicates that the above quote also contains deixis time for the period that will come.

\section{iv. Discourse Deixis}

"Saudara-saudara, Dokter Diaz ini adalah seorang pelajar yang bermutu tinggi di bidang gigi sehingga ia sangat ahli. Tak perlu diragukan kemampuannya, sama sekali tak perlu! Kalian dengar itu!"

(Source: Maryamah Karpov's novel, p. 462)

This data excerpt is a short speech from the Chairperson of Karmun who tried to convince residents that Dokter Diaz is a dentist whose abilities are not to be doubted. In the quote, at the beginning of the speech the Chairperson of the Carmelites mentioned directly the name of a dentist, Dr. Diaz. The next statement, the Chairperson of Karmun no longer uses that name, but replaces it with the pronoun person is Ia. So, the word ia refers to or point to the dentist figure previously mentioned by the Chairperson of the Karmun. Such a pattern shows an anaphoric discourse deixis.

Deixis discourse katafora is not found in the novel Maryamah Karpov by Andrea Hirata, so there is no data that can be displayed by researchers.

\section{v. Social Deixis \\ "Mohon maaf, Pak Cik, apakah sudah pernah ke Belitong sebelum ini?"}

(SourceL Novel Maryamah Karpov, p. 69)

The MK 060 data excerpt is a conversation between the figure of Bang Zaitun and a Chinese man who will work as the head of bookkeeping on an oil palm plantation in Belitong. In the quote Bang Zaitun uses the greeting of Pak Cik as a form of greeting politeness for the Belitong socity. This greeting also marks the culture of the Belitong people as a Malay tribe. This greeting is indicated or referred to as an adult male. An additional form of greeting that aims to refine the intent is honorific deixis social.

\section{Discussion}

Reading literature is essentially communicating indirectly with the authors of the writings we read. For this reason, between readers of literature and authors must have an understanding of language and meaning itself. Because, the 
success of communication can be achieved if there is an understanding between speakers and opponents of speech or in other words the opponent can understand the meaning of speech [1]. For this reason, studying the meanings conveyed by speakers (writers) and interpreted by listeners directs the reader to the action of studying language with a pragmatic theory.

As well as literature, the reader must be able to capture the messages conveyed by the author through the fabric of the story. The explicit message may be easily understood by the reader. But the literary literature is a work of imagination that is full of connotation content in it, certainly contains many messages or meanings that are implicit in nature. Just mention the Laskar Pelangi novel and Mimpi-Mimpi Lintang Maryamah Karpov by Andrea Hirata. The researcher openly acknowledges that the symptoms and phenomena of language are very nicely displayed by the author (Andrea Hirata) in describing event after event so that intertwining becomes a slick, cool, entertaining and has a depth of meaning that really deserves praise. No wonder the novels became very good on the market (became a best seller) and won various prestigious events [27, 28].

Related to pragmatics, of course in both novels they contain language phenomena and symptoms that deserve to be studied with this theory. Evidently, various studies of the two novels have been carried out using a pragmatic approach. The focus of the study or research is different, because pragmatics itself is a field of science which is divided into four focus studies namely deixis, presuppositions, implicature, and speech acts. This study itself uses a pracmatic approach by focusing on aspects of implicature and deixis in both novels.

The results of this study prove that in both novels, the symptoms of pragmatics have a high level of similarity. For example, in the aspect of implicature, researchers found three kinds of implicatures, namely conventional implicatures, presuppositions, and nonconventional implicatures. The search for this variety of implications refers to the concept put forward by Grice, Cole and Morgan [3]. As a result, the concepts and findings go hand in hand. Furthermore, by using the pragmatic concept proposed by Grevisse and Goosse [26], researchers explore the form of implicature used in both novels. The result, between the Laskar Pelangi novel and Mimpi-Mimpi Lintang Maryamah Karpov by Andrea Hirata, together uses implicatures, which are in the form of statement sentences, question sentences, command sentences, and exclamation sentences.

In addition to implicature, deixis in the Laskar Pelangi novel and Mimpi-Mimpi Lintang Maryamah Karpov by Andrea Hirata also has a high level of similarity. With reference to Lyons's theory [5] five forms of deixis are found in both novels namely individual or person deixis, place deixis, time deixis, discourse deixis, and social deixis. Individualexexists in this study were found to be two, namely eksis persona for the first person and eksis persona for the third person. Place deixis is also divided into three, namely proximal, semiproximal, and distal deixis. Deixis time was thus divided into three namely deixis past, deixis present or current and future deixis will come or the future. Discourse deixis is divided into two, namely anaphora and katafora. Dieksis katafora is not found in Maryamah Karpov's novel by Andrea Hirata. Only this is the difference between the findings of the two novels. Social deixis is divided into two, namely deixis euphemism and deixis of honorifics.

This finding is in line with some of the results of previous studies specifically on aspects of social deixis, such as Zanto and Rissman research [27], Junianto [28], and Rachmanita [29].

\section{Conclusion}

The variety of implicatures contained in the novel Laskar Pelangi by Andrea Hirata are divided into three, namely conventional implicatures, presupposition implicatures, and nonconventional implicatures. The various implicatures are then realized in four forms, namely sentence statements, command sentences, question sentences, and exciting sentences. Similarly, the novel Laskar Pelangi novel by Andrea Hirata Maryamah Karpov was found to range and form implicatures same.

Deixis in the novel Laskar Pelangi by Andrea Hirata can be divided into five, namely individual deixis, place deixis, time deixis, discourse deixis, and social deixis. Individual deixis is divided into two, namely the first person deixis and the third person deixis. Deixis is divided into three, namely proximal deixis, semiproximal deixis, and distal deixis. Deixis time divided into three namely deixis plainly past, deixis present, and deixis future will come. Discourse deixis is divided into two, namely anaphora deixis and katafora deixis. Social deixis is divided into two, namely deixis euphemism and deixis of honorifics. The five deixis are also found in Maryamah Karpov's novel. It's just that, in Maryamah Karpov's novel, the variety of deixis in the discourse of katafora is not found.

\section{References}

[1] J. Nurkamto, "Developing Language Teacher Professionalism Through Reflective Teaching1," Cakrawala Baru Lib. Amicorum Untuk Prof. Soenjono Dardjowidjojo, Ph. D., p. 139, 2003.

[2] D. Crystal, "The Cambridge encyclopedia oflanguage," Cam Bridg. CambridgeUniversityPress, 1987.

[3] H. P. Grice, P. Cole, and J. L. Morgan, "Syntax and semantics." 1975.

[4] Y. Huang, The Oxford handbook of pragmatics. Oxford University Press, 2017.

[5] J. Lyons and L. John, Linguistic semantics: An introduction. Cambridge University Press, 1995.

[6] Y. Sudaryat, "Meaning in Discourse of Semantic and Pragmatic Principles," Bandung: Yrama, 2009.

[7] D. Mulyana, "Ilmu komunikasi," Bandung PT Remaja Rosdakarya, 2005. 
[8] P. W. J. Nababan, "Ilmu pragmatik (teori dan penerapannya)," Jakarta: Depdiknas, 1987.

[9] A. Chaer and A. Leonie, "Early introduction sociolinguistics." Jakarta, 2004.

[10] F. Djajasudarma, "Discourse and Pragmatics," Bandung: Refika Aditama, 2012.

[11] A. Rani and B. Arifin, "Martutik," Anal. Wacana Sebuah Kaji. Bhs. dalam Pemakaian. Malang Bayumedia Publ., vol. 25, 2006.

[12] J. R. Searle, F. Kiefer, and M. Bierwisch, Speech act theory and pragmatics, vol. 10. Springer, 1980.

[13] J. R. Searle, Speech acts: An essay in the philosophy of language, vol. 626. Cambridge university press, 1969.

[14] L. S. Aslinda, "Pengantar sosiolinguistik," Bandung PT Refika Aditama, 2007.

[15] P. Grice, "Logic and conversation (1967 William James lecture at Harvard University); reprinted in," Stud. W. Words, 1967.

[16] A. Lubis, "Hamid Hasan Lubis. 1991," Anal. Wacana Pragmatik, 1991.

[17] G. Brown and G. Yule, Analisis wacana. Penerbit PT Gramedia Pustaka Utama, 1996.

[18] N. E. Rusminto, "Analisis Wacana Bahasa Indonesia (Buku Ajar)," Bandar Lampung Univ. Lampung, 2009.

[19] B. K. Purwo, Deiksis dalam bahasa Indonesia. PT Balai Pustaka (Persero), 1984.
[20] D. Pendidikan and R. I. Kebudayaan, "Kamus Besar Bahasa Indonesia (KBBI)," Balai Pustaka, Jakarta, 1995.

[21] B. Y. Cahyono, "How English Intensive Course Program Affects the English Proficiency of Students of Teachers' Colleges in Indonesia," Tak. from http//puslit. petra. ac. id/journals/letters, vol. 4, no. 1, pp. 23-35, 2002.

[22] M. A. Semi, Metode penelitian sastra. Angkasa, 1993.

[23] B. Nurgiyantoro, "Teori Pengkajian Sastra Fiksi." Yogyakarta: GM University Press, 2002.

[24] R. Stanton, Teori fiksi robert stanton. Pustaka Pelajar, 2007.

[25] H. G. Tarigan, Prinsip-prinsip dasar sastra. Penerbit Angkasa, 1984.

[26] M. Grevisse and A. Goosse, "Nouvelle grammaire française. 3 éme édition," Louvain-la-Neuve: De Boeck-Duculot, 1995.

[27] T. Zanto and J. Rissman, "Brain Mapping: An Encyclopedic Reference,” 2015.

[28] D. Junianto, "Pemakaian Deiksis Sosial dalam Novel Laskar Pelangi Karya Andrea Hirata." Universitas Muhammadiyah Surakarta, 2010.

[29] A. A. Rachmanita, "Deiksis Sosial Dalam Novel Sang Pemimpi Karya Andrea Hirata dan Implikasinya Terhadap Pembelajaran Bahasa dan Sastra Indonesia di SMP,” 2016. 